\title{
Synthesis for Further Discussion
}

\section{Luomanen, Petri Tuomo Jaakko}

Brill

2017

Luomanen, P T J 2017 , Synthesis for Further Discussion . in P Luomanen, A B Pessi \& I Pyysiäinen (eds), Christianity and the Roots of Morality : Philosophical, Early Christian, and Empirical Perspectives. Philosophical Studies in Science and Religion, no. 8 , Brill , Leiden , pp. 296-301. https://doi.org/10.1163/9789004343535_020

http://hdl.handle.net/10138/312064

https://doi.org/10.1163/9789004343535_020

unspecified

acceptedVersion

Downloaded from Helda, University of Helsinki institutional repository.

This is an electronic reprint of the original article.

This reprint may differ from the original in pagination and typographic detail.

Please cite the original version. 


\section{Synthesis for further discussion}

Petri Luomanen

The commentaries at the end of the three main parts of the book have already provided cross-disciplinary summaries and reviews. There is no need to summarize those discussions here. As an overall conclusion it is more appropriate to try to summarize how the book answers the core question that was raised in the introduction: What, if any, is the role of religion, especially Christianity, in morality, pro-social behavior, and altruism?

Furthermore, when all the articles and commentaries are viewed together, some recurrent themes and interesting links across the main parts emerge.

In practice, contributions in this volume mostly deal with religion and religious communities in the Judeo-Christian religious tradition. Thus, the results cannot necessarily be generalized to cover all religions. However, there are some cross-cultural aspects in the discussion, especially when it includes cognitive considerations. Therefore, I am occasionally speaking of "religion" in the following, but the reader is advised to keep in mind the restricted perspective of the volume.

Although the contributors and commentators approach the topic from diverse disciplinary areas with their own specific methodological traditions and discourses typical of their disciplines, they are practically unanimous in maintaining that morality does not necessarily require religion. Religiously unaffiliated persons or atheists are also capable of solving moral problems and pursuing moral goals. In some areas they may be even better tuned for seeing moral obligations or perceiving injustice than members of religious communities. In Nancy Ammerman's research religious toleration and concern for nature came up as examples of that kind of orientation. Heikki Räisänen takes up the case of Stoics as a possible example of ethical universalism that exceeds the ethical universalism in early Christian sources where universalism seems to be restricted by in-group concerns.

However, this does not mean that morality and pro-social behavior could not benefit from religion. Several articles in the volume argue for ways in which this could happen and some even bring forth cases where this seems to be empirically verifiable. 
Ammerman's research shows that in the North-American cultural context those who participate in religious activities (informants included Christians, Jews, and Mormons), "have a fuller vocabulary of moral concerns and a more active engagement in pursuing those concerns, as compared to non-participants." Persons un- or disaffiliated with North-American religious communities also have moral concerns but they are more likely to appoach moral problems from a more general structural and political point of view. They are also more likely to feel powerless in the face of moral problems, lacking the kind of infrastructure for voluntary service activities that members of religious congregations possess. Grace Davie cites in her commentary article similar results from Robin Gill's research in British context. These empirical studies bring us to the first possible effect of religion on morality: (1) The significance of religion, or better, religious communities for morality is their ability to cultivate moral thinking and to enable voluntary pro-social service.

If Ammerman's conclusion about the "fuller vocabulary of moral concerns" of members of religious communities is valid, the result reinforces the role Ilkka Pyysiäinen attributes to religion in moral considerations: "Religion only provides a cognitively effective way of explaining our moral intuitions to ourselves and to expressing them." However, Ammerman's conclusions go even further because religion also seems to boost pro-social activity. This brings to mind James's pragmatism, as presented in Pihlström's article, the "energizing of moral life" which would provide a practical justification for theism - although the kind of energizing that is exemplified in Ammerman's research data probably has more to do with social interaction than preoccupation with theistic beliefs, which actually brings us closer to Deweyan pragmatism. In any case, because religion is not a prerequisite for morality, empirical data leaves room for the kind of pragmatist philosophical solutions discussed in Pihlström's article.

The reasonable philosophical solution that takes into account empirical evidence has to be sought in moral religion or ethical theology rather than religious morality or theological ethics — or in "mutual holistic adjustment, with no one-way grounding either way" as Philström suggests. The idea of natural moral law that appears in different forms in traditional Catholic and Protestant theologies is, of course, also compatible with this, as is also pointed out in the commentaries of Knuuttila and Saarinen. 
In my view, John Dewey's naturalized pragmatism and even Richard Rorty's neopragmatist philosophy partly accord with Gerd Theissen whose delineation of evolutionary theology I discuss in my own article. Theissen defines evolutionary epistemology, which also covers religious knowledge, as follows:

Evolutionary epistemology regards the hypothesis of human knowledge as a continuation of that comprehensive process of adaptation of life to reality which governs all organic structures. Knowledge is the adaptation of cognitive structures to reality, the accommodation of thought to experience. Conversely: life forms knowledge.

This obviously accords with Dewey's goal of bringing religion "down to earth" as Pihlström puts it. Theissen also agrees with the Deweyan position in his understanding of experience. Theissen's evolutionary epistemology entails a notion about "existential experience of resonance" that is qualitatively the same in religious and in other spheres of life: in nature, art, music, and in interaction with other human beings.

Pihlström's discussion of Rorty's neopragmatism takes up Rorty's example of what to say to totalitarian secret police when they come. In Rorty's neopragmatic world there is nothing to say. Pihlström challenges this, arguing that it is precisely in pragmatist perspective that theological ideas should be evaluated on the basis of their ability to help people live ethically, and if ethically responsible theology or metaphysics does this, it should be justified. In this discussion, and in Pihlström's concluding considerations, the reality of evil is taken seriously. This is also what Theissen does in his evolutionary theorizing. Theissen's solution is to put cultural evolution to counteract harsh biological natural evolution. This sounds like an inherently contradictory solution - to put evolution into play against evolution - and Theissen may not have managed to solve all the theoretical problems related to this. He seems to be aiming at humans taking their responsibility as entrepreneurs in guided cultural evolution seriously. Whether this solution actually means stepping away from the evolutionary paradigm cannot be decided here. Be that as it may, these considerations have brought us to the second possible moral benefit 
from religion: (2) Religion, and especially Christianity in Theissen's model, helps fight evil.

Rorty's neopragmatism addresses the existential condition of humans left totally alone with their ethical considerations and solutions to moral problems. There are no theistic excuses available. This existential condition is also addressed in Ojakangas's article. His consideration of the problem of theodicy leads him to conclude: "If the ethical is exhausted in the notion of responsibility, then the atheist position is certainly more ethical. For the atheist position entails, not only that I am responsible for that evil I do, but also and more fundamentally that I am responsible for the very definition of evil." However, Ojakangas offers a way out for the religious position that makes it possible for religion to have a positive impact on morality, and this leads us to the third possible positive effect. If ethics is not about responsibility but about happiness, as it was for the ancient Greeks then: (3) "Religion is a means to alleviate the pain of man who walks here on earth under the burden of responsibility."

As we have seen above, the good side in Theissen's highly abstract evolutionary analysis is that it makes possible comparison with some moral philosophical positions. However, the downside of the abstract discussion is, as I point out in my own article, that it leaves open many questions about evolutionary processes on the grassroots level. My contribution is an attempt to develop some tools for more detailed analysis, taking into account the development of early Christian traditions, as they can be detected in the literary sources available to us, and their reception among early Christian communities.

Analyses of the earliest layers of Jesus traditions in Q reveal that from very early on moral exhortation was motivated both by referring to God's benevolence observable in the way he takes care of "birds and flowers" and by referring to future judgment. When Q traditions were elaborated by the editor(s) of Matthew's gospel, the themes of final judgment and community control became even more pronounced. Altruistic ideals were more prominent in the early phases of the Jesus movement but they became balanced with more means of controlling free riders. One of the "strategies" was to emphasize final judgment (there were also other means, rituals for instance). Or to express the same in an evolutionary framework: traditions and communities that were able to balance altruism survived better. Although the idea of final judgment may not be to the taste of modern 
liberal Christians, historical evidence shows that there is no doubt about its force.

Cognitive experiments confirm this: When people imagine themselves to be watched by human or supernatural agents their sensitivity to act according to their cultural moral norms is heightened. Thus the fourth possible way that religion supports morality is: (4) $A$ belief in supernatural surveillance and punishment (SSP) supports morality.

However, it is important to keep in mind that this mechanism is not specific to religion. It is rather one example of the hybridity of religion. Cognitive mechanisms that appear in human behavior and culture in general also make their way into the religious sphere of life. Moreover, as Petri Ylikoski shows in his article, the hypothesis that SSP was an important factor in the evolution of human cooperation is false (in the case of the early SSP hypothesis) and ungrounded (in the case of the late hypothesis).

Because the norms of Christian morality are generally thought to be quite similar to Jewish and Greco-Roman moral teaching, Lauri Thurén focuses in his article on the motivation of morals by applying modern argumentation analysis to the First Letter of Peter and Paul's Letter to the Romans. According to Thurén, the motivating factors are Christians' "novel status as God's chosen people" (1 Peter) and "life in the Spirit" or "in Christ" (Romans). As Thurén notes, this kind of motivation seems to reflect Monroe's thesis that people's self-image and identity motivate their altruistic behavior.

As far as I can see, Räisänen agrees with the idea that Christians' new identity “in Christ" could — or at least according to Paul it should — result in an ethically responsible way of life. However, Räisänen's examples of the downsides of heightened in-group identity are a healthy reminder that it is difficult to strike a balance. Heightened in-group identity may turn into hatred towards outsiders as well. Universality always grows from particularity as Syreeni argues in his article. Matthew may have come close to an optimal balance (but not harmony!) between universalism and particularism when developing the literary and thematic composition of the Sermon on the Mount, at least if judged on the basis of its reception.

Monroe's empirical research has not verified any causal effect between religion and altruism. In this regard it differs from Ammerman's results that reveal at least a positive correlation between religion and morality (a causal relation is more difficult to prove, especially on a general level, as Saarinen points out in his commentary). However, 
Monroe's theory about moral choice that she has developed on the basis of her research does leave room for religion to affect moral behavior if religion is able to shape identity. This leads us to the fifth possible positive impact of religion on morality: (5) Religion may support moral behavior by creating and cultivating social identity on the basis of which people make spontaneous moral judgments, acting accordingly.

The results of experimental research that Anne Birgitta Pessi discusses in her article show clearly that the general public and actors in the public sector see a clear link between Christianity and morality and expect Christian churches to be active in supporting welfare. Although professional theologians and philosophers disagree, this may indicate that in the mind of the general public it is the job of religion, and especially Christianity, to make ethics possible and to act accordingly. Furthermore, taking her lead from Taylor, Pessi contends:

I would argue strongly that religious institutions, particularly through their role in combating social problems, may offer such "institutions of authenticity." Through their words and deeds, they may offer trustworthy horizons of significance at which words and deeds speak the same language, even in the context of privatized faith and ideological frames.

This brings us to the sixth possible impact (which is closely related to points 1 and 5): (6) Religion may enhance solidarity and trust in society by acting as a "trustworthy horizon of significance."

The colleagues who have contributed to this volume, and my co-editors, are free to disagree (or agree) with the above considerations. This cooperation with colleagues from different fields - which first led to a conference and has now produced this volume - has been most rewarding. The main reason is that different methodological perspectives and scholarly discourses have introduced new concepts and opened new ways to look at themes that many of us have discussed only within our own disciplines. While the connections and similarities I have traced above may give a too harmonious picture of the overall undertaking, I trust that these considerations will be put into the correct perspective. Let the discussion continue. 